\title{
Energy aspects of using of water-hydrocarbons emulsion as a fuel for diesel engines
}

\author{
JEL: Q01 DOI: 10.24136/atest.2019.061 \\ Data zgłoszenia: 15.12.2018 Data akceptacji: 08.02.2019
}

The recent development of internal combustion engines (ICE) goes towards the meeting of increasingly stringent requirements imposed to reduce toxic exhaust emissions and fuel consumption and thus to strive for carbon diox-ide abatement and against depletion of global natural resources. The research on engines fueled by waterhydrocarbons emulsions has already a long tradition. So far, tests were based on emulsions obtained in chemical reactions. In this paper, similar analysis results have been presented, but the waterfuel emulsions used for the tests were obtained with making use of the cavitation effect. For this reason a unique cavitator was developed, which was then used to produce water-hydrocarbons emulsions of common, mineral and synthetic diesel fuel. Both of these fuels as well as their water emulsions with $20 \%$ water content by volume, were used for tests. The ESC (European Stationary Cycle) test conditions were determined and the engine was tested on engine dyna-mometer in accordance with the predetermined ESC test conditions. During the tests, under close scrutiny, en-gine emission and fuel consumption levels were measured. The tests it be more time repeat (with every liquid to engine fueling was 34 times) to achieve the statistical assessment of the results. By the use of emulsions was found to result in a significant reduction in the consumption of diesel fuels. This result is statistically signifi-cant.

Słowa kluczowe: IC engines, fuel consumption, hydrocarbons-water, emulsions

\section{Wstęp}

The work was undertaken to evaluate the fuel consumption of an internal combustion engine (ICE) powered with emulsions of hydrocarbon fuels and water. The work described here was done as a preliminary study, which was also aimed at verifying whether this direction of work may be considered promising.

Nowadays we hope that with this solution we will reduce one part of $\mathrm{CO} 2$ emissions and eliminate the so-called low emissions especially in large cities.

Today's situation is not satisfactory.

Road transport in the European Union (EU) generates about one-fifth of total carbon dioxide emissions and the progress in reducing of this emissions are little [13].

Figure 1 shows that in 2001 the average $\mathrm{CO} 2$ emission from the vehicle (in the test on the chas-sis dynamometer) was $170 \mathrm{~g} / \mathrm{km}$ (with standard deviation about $20 \mathrm{~g} / \mathrm{km}$ ). In 2015, it was only 116 $\mathrm{g} / \mathrm{km}$ (with a standard deviation of $10 \mathrm{~g} / \mathrm{km}$ ). Significant progress seems to have been achieved. However, the result from natural exploitation differs from the test results. In 2001 it was 7\% (with a standard deviation of $2 \%$ ). In 2015, the difference between the results from operation and the test is, on average, $43 \%$ (with a standard deviation of $5 \%$ ). Thus, the average $\mathrm{CO} 2$ emission in vehicle operation in 2001 was $182 \mathrm{~g} / \mathrm{km}$, while in 2015 it was 166 $\mathrm{g} / \mathrm{km}$.

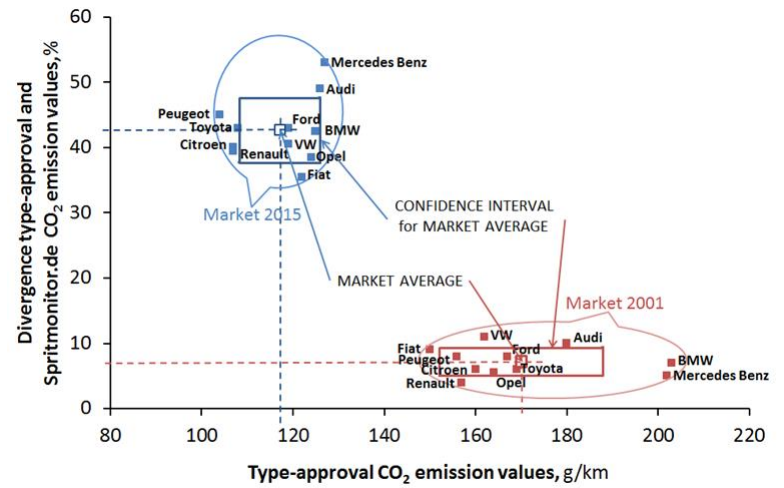

Fig. 1. CO2 emission changes within 15 years of automotive development (based on [13])

The actual reduction in operational CO2 emission (from 2001 to 2015 ) is $8.8 \%$. This is not a result that corresponds to the social needs and the amounts incurred to obtain it. And emissions increase every year. Therefore, vehicle manufacturers are required to achieve mandatory emission targets for new vehicles. By 2050, a $60 \%$ reduction in emissions of carbon dioxide in the transport sector in the EU is being promoted and one from more ways is the using of new fuels especially with hydrogen content also in form as the hydrogen is in water. From this reason are important to know if that is possible with water-hydrocarbons fuel mixture $[4,5,10,14]$.

Water-in- diesel fuel emulsions may be obtained chemically, by adding detergents $[1,2.3,6,7,9,11,12]$ or in result of physical processes, e.g. with making use of the cavitation effect [10] - for example.

In the work presented here, water-hydrocarbon's emulsions were obtained by employing the latter [10] method.

Two diesel fuel types were used for the tests:

- mineral diesel fuel (DF) and

- synthetic diesel oil (GTL).

Moreover, water emulsions $(20 \% \mathrm{v} / \mathrm{v})$ of these fuels, i.e. water emulsions of mineral and syn-thetic diesel oils (DF2OH2O and GTL2OH2O respectively), were also used.

The emulsions were produced with the use of a prototype cavitator - device of special design.

The emulsion-making system included two tanks. The tanks were filled with the liquids neces-sary for making the emulsion, i.e. diesel oil and water. A pump provided in the system forced the liquids from the system tanks via a gravitational column to an cavitator, from where the liquids returned to the tanks in a closed cycle.

However the cavitation is a relatively complex phenomenon caused by a drop in the pressure of the fluid, the both liquids (fuel and water) were perfectly mixed together.

The emulsions produced were homogenous; however, they underwent emulsion breaking with time. For the mineral and synthetic diesel oil, the emulsion breaking took place after about ten minutes and after about seven minutes, respectively. For this reason the physical-chemical proper-ties of the emulsions produced were not 
examined, but most likely they were not in conformity with the standard specifications applicable to diesel fuel.

Diesel fuels; (DF and GTL) and hydrocarbons - water emulsions of both fuels obtained by cavi-tation are used for the fueling of diesel engines in tests.

The tests were to be carried out with following the ESC test procedure $[9,14]$. The ESC test was introduced simultaneously with the ETC (European Tran-sient Cycle) and ELR (European Load Response) test procedures. It is used for the evaluation of exhaust emissions of $\mathrm{Cl}$ engines. In Europe, it has been used since 2000 (Directive 1999/96/EC of 13 December 1999). It consists of 13 modes and has superseded a 13 mode test $R 49$.

The test is run at selected engine crankshaft speeds and loads. Four crankshaft speed values are set, with one of them being the idle engine speed and the other being selected in a special way; test loads are applied to the engine at the said preselected engine speeds. Actually, the test is carried out in the conditions of engine lowidle speed and three load response characteristics. Before the test is begun, specific reference points should be located on the maximum engine power curve vs. crankshaft speed. The location of these points has been depicted in Fig 2.

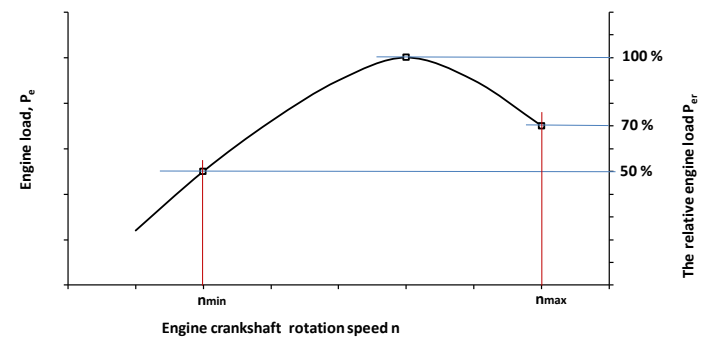

Figure 2. Location of the reference points on the maximum engine load curve vs. crankshaft rotational speed, needed to determine the ESC test parameters

At each of the above crankshaft speeds, measurements are carried out for four engine loads corresponding to $25 \%, 50 \%, 75 \%$ and $100 \%$ of the engine power output at the specific speed, which has been mapped in Fig. 3 as points representing individual ESC test modes in the per cent engine load / per cent engine speed coordinate system.

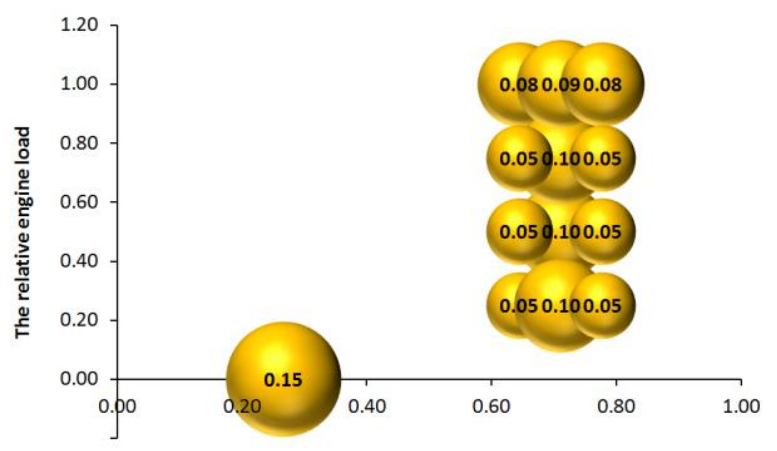

The relative rotational speed of the engine crankshaft

Fig. 3. Mapping of the points representing individual ESC test modes in the per cent engine load as function of per cent rotational speed of the engine crankshaft, with the participation of individual phases in the test (inside the bubbles

Water-hydrocarbons emulsions obtained by cavitation used for the fueling of diesel engines
Apart from the 13 ESC test modes where the engine loads were as previously specified, the test included a mode where the engine was run with its idle speed (at, approximately, zero engine load).

In consideration of the fact that actually the intensity of engine operation is not uniform all over the whole engine load and speed range, weighting factors have been introduced for this no uniformity to be taken into account at determining the exhaust emission values.

The ESC test parameters have been presented in Table 1.

Tab. 1. ESC test parameters and mode number

\begin{tabular}{|c|c|c|c|c|}
\hline \hline Phase nr & $\begin{array}{c}\text { The relative } \\
\text { engine load }\end{array}$ & $\begin{array}{c}\text { The relative } \\
\text { rotational } \\
\text { speed of the } \\
\text { engine } \\
\text { crankshaft }\end{array}$ & $\begin{array}{c}\text { Phase partici- } \\
\text { pation in the } \\
\text { test }\end{array}$ & $\begin{array}{c}\text { Phase time, } \\
\text { min }\end{array}$ \\
\hline 1 & 0.27 & 0.00 & 0.15 & 4 \\
\hline 2 & 0.64 & 1.00 & 0.08 & 2 \\
\hline 3 & 0.71 & 0.50 & 0.10 & 2 \\
\hline 4 & 0.71 & 0.75 & 0.10 & 2 \\
\hline 5 & 0.64 & 0.50 & 0.05 & 2 \\
\hline 6 & 0.64 & 0.75 & 0.05 & 2 \\
\hline 7 & 0.64 & 0.25 & 0.05 & 2 \\
\hline 8 & 0.71 & 1.00 & 0.09 & 2 \\
\hline 9 & 0.71 & 0.25 & 0.10 & 2 \\
\hline 19 & 0.78 & 1.00 & 0.08 & 2 \\
\hline 11 & 0.78 & 0.25 & 0.05 & 2 \\
\hline 12 & 0.78 & 0.75 & 0.05 & 2 \\
\hline 13 & 0.78 & 0.50 & 0.05 & 2 \\
\hline
\end{tabular}

1.Results of bench testing of an engine fueled with the liquids under tests

The tests were carried out on a compression-ignition engine MF PERKINS AD3.152UR with a conventional fuel feed system, (designed for being fed with mineral diesel oil).

During the tests, standard engine settings were maintained.

The tests in the ESC test conditions were carried out on an engine test bed provided with a FROUDE DPX 4 water brake dynamometer. At first, however, the ESC test conditions had to be determined. Obviously, differences in engine performance, especially in the maximum power and torque vs. speed curves, were expected to result from feeding the test engine with the fuels under tests and with their emulsions. Therefore, the maximum engine performance curves were determined at the first stage of the tests. Based on this, a substitute maximum performance curve was plotted as the lower envelope of all the performance curves determined for the engines fed with the fuels under tests and with their emulsions. Such an assumption was made because of the necessity that the engine under tests should be subjected to identical load conditions represented by the same point on the engine performance curve regardless of the liquid used for engine fueling purposes ("fueling liquid"). The term "fueling liquid" is used here instead of "fuel" because the emulsions do not meet all the requirements of fuel standard specifications, especially the EN 590 standard.

The results obtained have been illustrated in Fig. 4. 


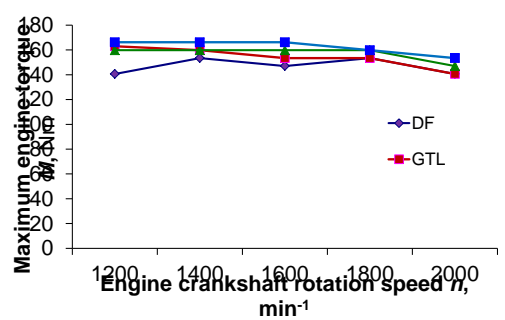

Fig. 4. Maximum torque vs. speed curves for the engine fueled with different liquids

As it can be seen in the graph, the curve of maximum torque vs speed is to register for the engine fed with a water emulsion with synthetically diesel fuel (GTL2OH2O). Feeding with a conven-tional diesel fuel (DF) lead to minimum of max performance of engine and this case was chosen as the substitute maximum performance curve because by all liquids those parameters are to achieve.

Based on this curve, the ESC test parameters were determined and maintained at the tests subsequently carried out.

Such test procedure was repeated of 34 times for every liquids. This was especially important to know for the statistical repeatability of measured and calculated results. This, in turn, was im-portant to correctly assess the possible differences in the engine's liquid consumption.

With the achieved data was the standard statistics carry out. Results of this work is have been summarized in table 3 .

If will be take in consideration first of all the liquid consumption, then the lowest consumption are registered by fueling the engine with the synthetically GTL fuel. Changing the fuel from stand-ard diesel oil to the GTL give a lowering the fuel consumption about $5 \%$. In opposite to them, fuel-ing the engine with water hydrocarbons emulsion gave the growing of liquids consumption. But the liquids is a mixture with only $80 \%$ of hydrocarbons. In this case interesting is that consumption of hydrocarbons are reduced by fueling with diesel oil mixture about $7 \%$ and by GTL mixture more than $14 \%$.

Tab. 3. Results of the experiments carried out in accordance with the ESC test procedure

\begin{tabular}{|c|c|c|c|c|}
\hline \hline Liquid & $\begin{array}{c}\text { Average, } \\
\mathrm{g} / \mathrm{kWh}\end{array}$ & $\begin{array}{c}\text { Variance, } \\
(\mathrm{g} / \mathrm{kWh})^{2}\end{array}$ & $\begin{array}{c}\text { Hydrocarbons, } \\
\mathrm{g} / \mathrm{kWh}\end{array}$ & $\begin{array}{c}\text { Hydrocarbons } \\
\text { reduction, } \%\end{array}$ \\
\hline DF & 304.18 & 1.58 & 304.18 & 0.00 \\
\hline GTL & 288.78 & 1.67 & 288.78 & -5.06 \\
\hline DF20H2O & 353.86 & 13.45 & 283.09 & -6.93 \\
\hline GTL20H2O & 324.74 & 5.13 & 259.79 & -14.59 \\
\hline
\end{tabular}

The results are very encouraging for further research and for putting them into operation, in particular in stationary engines. The question is if that are to achieve not only in laboratory test (but in real engine), especially that, as shown in Figure 5, the variances in powering the engine with emulsions are significantly greater than when supplied with diesel oil.

The results are better visible on the graph below.

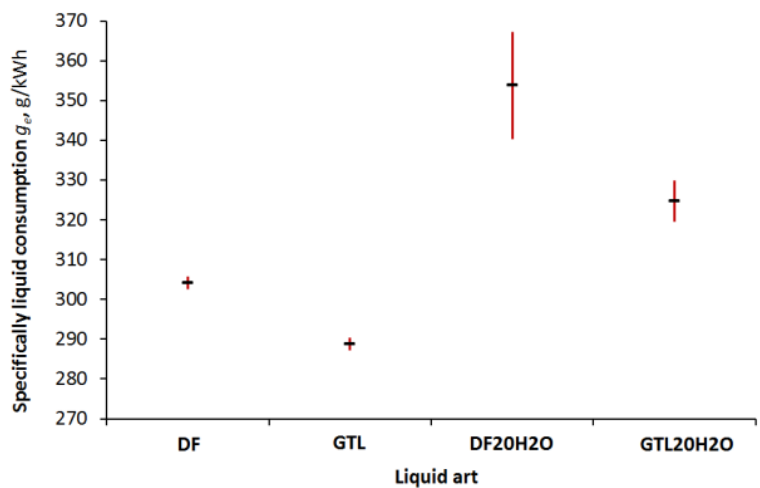

Fig. 5. Results of statistical assessment of liquid consumption data in the ESC test

To answer this question are no other way as a statistical research. Doe this reason are good to know if the differences in liquids consumption are statistically to be confirmed, therefore, whether it can be considered its significance on the basis of statistical analysis.

The complexed statistical analysis was carried out.

The analysis was carried out in three stages

- descriptive statistics (for information on means, standard deviations, variances, etc.),

- test (in this case Shapiro-Wilk), to confirm whether the data sets can be described by a spe-cific statistical distribution,

- Student test to determine if the differences of the data sets are significant.

Tab. 2. A sample set of specifically liquid (DF2OH2O) consumption results and calculated specific consumption of water-fuel emulsion, determined for the engine during the ESC test Mode

\begin{tabular}{|c|c|c|c|c|c|c|c|c|}
\hline Phase nr & $\begin{array}{c}\text { Crankshaft } \\
\text { rotation speed, } \\
\text { min-1 }\end{array}$ & $\begin{array}{c}\text { Crankshaft } \\
\text { relative rotation } \\
\text { speed }\end{array}$ & $\begin{array}{l}\text { Engine } \\
\text { load, } \\
\mathrm{Nm}\end{array}$ & $\begin{array}{l}\text { Relative } \\
\text { engine load }\end{array}$ & $\begin{array}{c}\text { Phase } \\
\text { duration, min }\end{array}$ & $\begin{array}{l}\text { Specifically liquids } \\
\text { consumption g/kWh }\end{array}$ & $\begin{array}{c}\text { Phase participation } \\
\text { in the test }\end{array}$ & $\begin{array}{c}\text { Share of liquid } \\
\text { consumption in the } \\
\text { test, } \mathrm{g} / \mathrm{kWh}\end{array}$ \\
\hline 1 & 600 & 0.27 & 1.96 & 0.00 & 4 & 499.95 & 0.15 & 74.99 \\
\hline 2 & 1450 & 0.64 & 141.91 & 1.00 & 2 & 250.72 & 0.08 & 20.06 \\
\hline 3 & 1600 & 0.71 & 67.76 & 0.50 & 2 & 324.98 & 0.10 & 32.50 \\
\hline 4 & 1600 & 0.71 & 102.28 & 0.75 & 2 & 284.75 & 0.10 & 28.48 \\
\hline 5 & 1450 & 0.64 & 70.96 & 0.50 & 2 & 255.28 & 0.05 & 12.76 \\
\hline 6 & 1450 & 0.64 & 106.75 & 0.75 & 2 & 282.79 & 0.05 & 14.14 \\
\hline 7 & 1450 & 0.64 & 35.16 & 0.25 & 2 & 404.80 & 0.05 & 20.24 \\
\hline 8 & 1600 & 0.71 & 136.16 & 1.00 & 2 & 301.40 & 0.09 & 27.13 \\
\hline 9 & 1600 & 0.71 & 33.88 & 0.25 & 2 & 444.14 & 0.10 & 44.41 \\
\hline 19 & 1750 & 0.78 & 140.00 & 1.00 & 2 & 327.58 & 0.08 & 26.21 \\
\hline 11 & 1750 & 0.78 & 34.52 & 0.25 & 2 & 583.24 & 0.05 & 29.16 \\
\hline 12 & 1750 & 0.78 & 104.84 & 0.75 & 2 & 342.34 & 0.05 & 17.12 \\
\hline 13 & 1750 & 0.78 & 69.68 & 0.50 & 2 & 370.21 & 0.05 & 18.51 \\
\hline & & & & & & & Sum of the test & 365.70 \\
\hline
\end{tabular}


The data of the descriptive statistics are as follow.

Tab. 4. The data of the descriptive statistics

\begin{tabular}{|r|r|r|r|r|}
\hline \hline & DF & GTL & DF20H2O & GTL2OH2O \\
\hline Average & 304.18 & 288.78 & 353.86 & 324.74 \\
\hline Standard error & 0.2158 & 0.2219 & 1.4864 & 0.3885 \\
\hline Median & 304.21 & 288.87 & 355.64 & 324.41 \\
\hline \begin{tabular}{r|r|r|r|} 
Standard \\
deviation
\end{tabular} & 1.2581 & 1.2937 & 3.6672 & 2.2651 \\
\hline Variance & 1.5829 & 1.6737 & 13.4486 & 5.1308 \\
\hline Kurtosis & -0.6626 & -0.0421 & -0.9249 & 0.6010 \\
\hline Skewness & -0.1548 & -0.0646 & -0.2853 & 1.0412 \\
\hline Range & 5.12 & 5.65 & 31.61 & 8.75 \\
\hline Minimum & 301.65 & 285.59 & 337.78 & 321.58 \\
\hline Maximum & 306.77 & 291.24 & 369.38 & 330.34 \\
\hline Sum & 10341.99 & 9818.38 & 12031.15 & 11041.12 \\
\hline Counter & 34 & 34 & 34 & 34 \\
\hline $\begin{array}{r}\text { Confidence } \\
\text { level (95,0\%) }\end{array}$ & 0.44 & 0.45 & 1.32 & \\
\hline & & & & \\
\hline
\end{tabular}

The data of the Shapiro-Wilk test calculations are given bellow.

Tab. 5. Shapiro-Wilk test calculations results

\begin{tabular}{|r|r|r|r|r|}
\hline \hline & DF & GTL & DF20H2O & GTL2OH2O \\
\hline$W_{\text {calc }}$ & 20.175 & 19.321 & 13.073 & 5.811 \\
\hline$W_{\text {kr }}$ & 0.934 & 0.934 & 0.934 & 0.934 \\
\hline & $W_{\text {calc }}>W_{k r}$ & $W_{\text {calc }}>W_{\text {kr }}$ & $W_{\text {calc }}>W_{\text {kr }}$ & $W_{\text {calc }}>W_{\text {kr }}$ \\
\hline
\end{tabular}

This test (Shapiro-Wilk) was used to assess whether average values of liquid consumption (from 34 ESC test repetitions for each liquid) are characterized by normal distribution. The presented data show that the hypothesis about the normality of distribution cannot be rejected.

After making sure that the respective distributions are normal distributions, it was possible to assess whether the differences between the consumption of individual liquids are significant. This was assessed using the t-Student test with the assumption of different variance values. Differ-ences were tested in relation to engine fueled with mineral diesel fuel (DF). The results of the analysis are showing here in the table 6.

Tab. 6. Calculated values of t-Student test and their reference to the critical values of this test

\begin{tabular}{|r|r|r|r|r|}
\hline \hline & DF & GTL/DF & DF20H2O/DF & GTL20H2O/DF \\
\hline t-Student(calc) & & 49.760 & 74.719 & 46.274 \\
\hline $\mathrm{t}_{\mathrm{kr}}$ Student & & 1.997 & 1.997 & 1.997 \\
\hline & & $\mathrm{t}_{\text {calc }}>\mathrm{t}_{\mathrm{kr}}$ & $\mathrm{t}_{\text {calc }}>\mathrm{t}_{\mathrm{kr}}$ & $\mathrm{t}_{\text {calc }}>\mathrm{t}_{\mathrm{kr}}$ \\
\hline & & & & \\
\hline
\end{tabular}

As is to seeing the differences in the consumption of individual liquids are important, so you can also expect that also under the Natural conditions of engine operation, the corresponding differences will also occur.

It remains to be clarified whether the differences in fluid consumption occurring in individual phases of ESC test are significant. Appropriate threestep calculations were performed (similar to those for the averages), and their final results (Student t-values) are summarized in Table 6.

Tab. 7. Calculated values of t-Student statistics for the comparison of the significance of the differ-ence in liquid consumption in individual phases of the ESC test

\begin{tabular}{|c|c|c|c|c|c|}
\hline \hline \multirow{2}{*}{$\begin{array}{c}\text { ESC } \\
\text { test } \\
\text { phase }\end{array}$} & \multicolumn{5}{|c|}{ Liquids } \\
\cline { 2 - 6 } & GTL/DF & $\begin{array}{c}\text { DF20H2O } \\
\text { /DF }\end{array}$ & $\begin{array}{c}\text { GTL2OH2O } \\
\text { /DF }\end{array}$ & $\begin{array}{c}\text { GTL2OH2O } \\
\text { /DF2OH2O }\end{array}$ & $\begin{array}{c}t_{k r} \\
\text { Student }\end{array}$ \\
\cline { 2 - 6 } & \multicolumn{5}{|c|}{ t-Student (calc) } \\
\hline
\end{tabular}

\begin{tabular}{|r|r|r|r|r|r|}
\hline \hline 1 & -7.776 & -83.868 & -3.206 & 81.629 & 1.997 \\
\hline 2 & 70.000 & 1.527 & 103.292 & 90.827 & 1.997 \\
\hline 3 & 68.269 & 35.129 & 104.608 & 47.225 & 1.997 \\
\hline 4 & 36.499 & -15.650 & 76.676 & 75.044 & 1.997 \\
\hline 5 & 67.567 & 7.656 & 28.568 & 19.387 & 1.997 \\
\hline 6 & -8.210 & -26.907 & -24.799 & -4.550 & 1.997 \\
\hline 7 & 35.985 & -9.568 & 10.177 & 19.982 & 1.997 \\
\hline 8 & 6.899 & -21.463 & -28.7079 & -8.825 & 1.997 \\
\hline 9 & 1.839 & -96.010 & -54.615 & -0.789 & 1.997 \\
\hline 10 & 7.891 & -42.050 & -39.567 & -4.191 & 1.997 \\
\hline 11 & 52.849 & -45.539 & -14.692 & 23.369 & 1.997 \\
\hline 12 & -31.913 & -90.855 & -75.020 & 17.821 & 1.997 \\
\hline 13 & -0.158 & 0.358 & -80.460 & -79.713 & 1.997 \\
\hline
\end{tabular}

As it can be see the differences do not occur only in a few cases. In comparison GTL to DF in phases 9 and 13 (operating conditions in these phases are included in table 2). in the case of a Gt $/$ DF comparison, the difference is not significant in the case of phase 13 , whereas in a negligible dif-ference when supplying the GTL2OH2O with reference to the DF20 power supply it occurs only in the case of phase 9 . In phase 9 , the engine operated at a rotational speed of $n=1600$ min- 1 and the torque was $M=34 \mathrm{Nm}$. in Phase $13, n=1750 \mathrm{~min}-1, M=70 \mathrm{Nm}$. These are not extreme conditions. The reasons for this should be clarified in subsequent studies.

\section{Conclusions}

An analysis of the test results has confirmed that the economic performance of contemporary compression-ignition $(\mathrm{Cl})$ engines may be improved by fueling such engines with synthetic diesel oil or with water emulsions of diesel oils. The maximum performance characteristics of the engine fueled with the synthetic diesel oil. Emulsions of diesel oils differed from each other. The highest torque values were achieved when the engine was fueled with the synthetic diesel oil; on the other hand, the engine developed the lowest torque when it was fed with a water emulsion of this oil.

The fueling of the engine with the synthetic diesel oil was found to lead to a reduction in the volumetric fuel consumption determined in the ESC test conditions by about $5 \%$ in comparison with the mineral diesel fuel consumption. The fueling of the engine with a water emulsion of the synthetic diesel oil led to further reduction in the volumetric fuel consumption by almost $14 \% \mathrm{v} / \mathrm{v}$ in total. Such results should be considered significant.

When a water emulsion of the mineral diesel oil was used to fuel the engine, the volumetric consumption of this oil was reduced by about $7 \%$, which should again be considered a promising result.

All this results, after statistically assessment of measuring data, are to understood as significant one should therefore expect similar results obtained with other engines, not only like the one on which the tests were carried out.

The tests have shown a possibility of fueling a $\mathrm{Cl}$ engine with water emulsions of diesel oils achieved short time within a short time before putting the fuel directly into the engine with help of cavitation phenomena. Due to relatively fast breaking of the emulsions under tests (obtained from a physical process with making use of the cavitation effect), the fuels thus prepared should be chiefly used for stationary engines or engines of vehicles of more than $3.5 \mathrm{Mg}$ total mass. During the next works, the issue of the impact of emulsions used as a fuel on the engines durability and reliability should be explored and clarified especially in natural exploitation.

\section{Bibliography}

1. Chłopek Z.: Pojazdy samochodowe. Ochrona środowiska naturalnego; WKit, Warszawa 2002 
2. Abass KI. The Impact of Various Surfactants on the Water-inDiesel Fuel Emulsions. 2017:

https://www.researchgate.net/publication/316702079_The_Impa ct of Various Surfactants on the Water-in-

Diesel_Fuel_Emulsions

3. Dibofori-Orji, A.N.: Critical Processes Involved in Formulation of Water-in-Oil Fuel Emulsions, Combustion Efficiency of the Emulsified Fuels and Their Possible Environmental Impacts. Research Journal of Applied Sciences, Engineering and Tech-

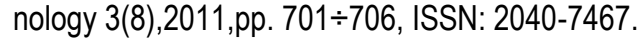

4. Emberson DR Ihracska B Imran S Diez A Lancaster M Korakianitis $\mathrm{T}$. Hydraulic characterization of Diesel and water emulsions using momentum flux. Fuel 162 (2015) 23-33

5. Ithnin AM Yahya WJ. Emulsifier-free Water-in-Diesel emulsion fuel: Its stability behaviour, engine performance and exhaust emission. Fuel 215: pp. 454-462 · December 2017

6. Jankowski, A.: Influence of chosen parameters of water fuel micro emulsion on combustion processes, emission level of nitrogen oxides and fuel consumption of $\mathrm{Cl}$ engine. Journal of KONES Powertrain and Transport, Vol. 18, No. 4, 2011.

7. Lin C Y Wang K H. The Fuel Properties of Three-Phase Emulsions as an Alternative Fuel for Diesel Engines. Fuel, 82, pp.

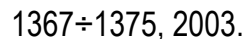

8. Khan M Y Hagos F Y. Current Trends in Water-in-Diesel Emulsion as a Fuel. The Scientific World Journal 2014(17):527472

9. Sitnik L J. Ekopaliwa silnikowe (Engine eco-fuels). Oficyna Wydawnicza Politechniki Wro-cławskiej (Publishing House of the Wrocław University of Technology), Wrocław, 2004

10. Sitnik L J, Dworaczyński M K Haller P. Water-carbohydron emulsions obtained by cavitation used for the fueling of diesel engines. Archiwum Motoryzacji (The Archives of Automotive Engineering) 2013 No 2 pp 53-64.

11. Tajima, H., Takasaki, K., Nakashima, M., Kawano, K., Ohishi, M., Yanagi, J. and Osafune, S.: Visual Study on Combustion of Low-Grade FuelWater Emulsion. COMODIA, 2001, July 1-4, Nagoya, 2001

12. Vu P H Nishida O Fujita H Harano W Toyoshima N Iteya M. Reduction of NOx and PM from Diesel Engines by WPD Emulsified Fuel. SAE Paper 2001-01-0152, 2001.

13. Tietge U Díaz S Mock $P$ German J Bandivadekar A Ligterink N. From laboratory to road. A 2016 update of official and 'realworld' fuel consumption and $\mathrm{CO} 2$ values for passenger cars in Europe WHITE PAPER November 2016 www.theicct.org

\section{Energetyczne aspekty wykorzystania emulsji węglowodorowo-wodnej jako paliwa silników diesla}

Rozwój silników spalinowych podażą w kierunku spełnienia coraz bardziej rygorystycznych wymogów narzucanych w celu zmniejszenia emisji toksycznych składników spalin i zużycia paliwa, a tym samym do redukcji emisji dwutlenku węgla i zapobieżeniu wyczerpywania się globalnych zasobów naturalnych. Badania silników zasilanych emulsjami wodno-węglowodorowymi mają już długa tradycję. Dotychczas testy były oparte na emulsjach otrzymywanych poprzez dodawanie związków chemicznych. W niniejszym artykule przedstawiono wyniki badań, w których emulsje uzyskano przy wykorzystaniu zjawiska kawitacji. Z tego powodu opracowano unikatowy kawitator, który był następnie wykorzystywany do produkcji emulsji wodno-węglowodorowych zwykłego, mineralnego oraz syntetycznego oleju napędowego. Oba te paliwa, a także ich emulsje wodne o $20 \%$ zawartości wody objętościowo, zostały użyte do testów ESC (Europejskiego Cyklu Stacjonarnego). Określono warunki badania wg ESC i przetestowano silnik na hamowni zgodnie $z$ tymi warunkami. Podczas testów zmierzono poziom emisji i zużycia paliwa. Przy każdym rodzaju paliwa testy powtarzano 34 krotnie aby uzyskać statystyczną ocenę wyników. Stwierdzono, że zastosowanie emulsji powoduje znaczne zmniejszenie zużycia olejów napędowych. Wynik ten jest statystycznie istotny.

Prof. Lech J. Sitnik, DSc., DEng. - Division of Automotive Engineering at Wroclaw University of Science and Technology.

Maciej K. Dworaczyński, MEng. - Division of Automotive Engineering at Wroclaw University of Science and Technology.

Piotr Haller, MEng. - Division of Automotive Engineering at Wroclaw University of Science and Technology.
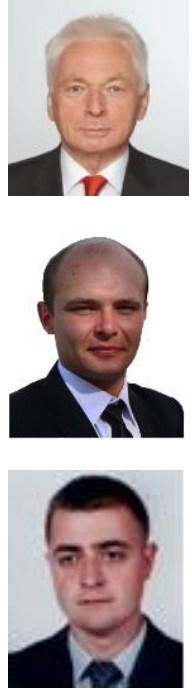